九州大学学術情報リポジトリ

Kyushu University Institutional Repository

Birds on the North Coast of the Sea of Ariake : II. The Relation between Food Habits of Sandpipers and Invertebrates in the Substrate

Kawaji, Noritomo

Zoological Laboratory, Faculty of Agriculture, Kyushu University

Shiraishi, Satoshi

Zoological Laboratory, Faculty of Agriculture, Kyushu University

https://doi.org/10.5109/23688

出版情報: 九州大学大学院農学研究院紀要. 23 (3/4)，pp.163-175，1979-03. Kyushu University バージョン：

権利関係 : 
J. Fac. Agr., Kyushu Univ., 23, 163-175 (1979)

\title{
Birds on the North Coast of the Sea of Ariake \\ II. The Relation between Food Habits of Sandpipers and Invertebrates in the Substrate
}

\author{
Noritomo Kawaji and Satoshi Shiraishi \\ Zoological Laboratory, Faculty of Agriculture, \\ Kyushu University 46-06, Fukuoka 812
}

(Received December 5, 1978)

\begin{abstract}
The analysis of stomach contents was conducted in sandpipers of five species (Calidris alpina, Xenus cinereus, Tringa brevipes, T. glareola, T. hypoleucos) collected on the north coast of the Sea of Ariake. A great number of polychaetes and gastropod molluscs were found in C. alpina, and a lot of polychaetes were also found in X. cinereus. In T, brevipes only fragments of crabs were found. In both T. glareola and $\mathbf{T}$. hypoleucos were found a number of skeletons of frogs. Analysing the relation between the invertebrates and the aggregation of birds, the distribution of $\mathbf{T}$. brevipes closely related with that of Crustacea, especially that of Brachyura. And the distribution of $\mathrm{C}$. tenuirostris closely related with that of small molluscs. In both $\mathrm{C}$. alpina and $\mathrm{X}$. cinereus, however, no relation was found between their distributions and any specific prey. There seemed to be two types of the sandpipers at the time of their migration. The first was relatively stenophagous species, such as T. brevipes and C. tenuirostris, which showed the specific preferences to the prey species. The second was the considerably euryphagous species, such as C. alpina and $\mathrm{X}$. cinereus, which showed fairly wide preferences to their preys.
\end{abstract}

\section{INTRODUCTION}

The north coast of the Sea of Ariake is famous for a great number of migrant shorebirds which feed invertebrates on the tidal flats. Investigations of food habits of sandpipers are usually conducted by either of three methods. The first method is the direct observation method, and preys picked up by birds are identified at the point by the use of a binocular or a telescope (GossCustard, 1969, 1970). In this method it is necessary to be familiar with the identification of prey invertebrates. But the observation of prey is very difficult in such sandpipers as the Dunlin Calidris alpina and the Great Knot C. tenuirostris, which chiefly feed by probing.

The second is the analysing of faeces (Feare, 1966), but the collection of them is very difficult on the mud flat. The third is the analysis of the stomach contents obtained from birds captured (e.g. Reeder, 1951; Holmes, 1966; Bengtson and Svensson, 1968). In addition to them, there is the analysing method of the pellets and droppings of sandpipers as Goss-Custard and Jones (1976) adopted. Although, in Japan, there have been many investigations on the analysis of stomach contents of birds, e.g. Ikeda (1956), only the Wild Bird Society of Japan (W. B. S. J.) (1975) reported on sandpipers. 
We analysed stomach contents of some sandpipers captured in autumn migratory season alone, and collected invertebrates in the substrate during all seasons. There is, accordingly, an inconsistency in the seasons when stomach and invertebrate samplings were conducted. The primary aim of this study, however, was to make clear the relation between the quantity of invertebrates and the aggregation of birds. Thus, we believe that our aim was achieved to considerable extent.

This investigation was part of the entrusted studies by Environment Agency under the title of "Fundamental studies on wildlife conservation" (Trustee: Prof. T. A. Uchida, Faculty of Agriculture, Kyushu University).

\section{STUDY AREA}

Yamato reclaimed land with an area of about 330 ha is separated from Yanagawa City by the Shiotsuka river, and from Takada Machi, Miike Gun, by the Yabe river (Fig. 1). This land is surrounded by a bank, of which about the lower one third is submerged at high tide. The tide receding, a mud flat appears at the outside of Hashimoto reclaimed land, Yanagawa City, which is situated on the opposite side of Yamato reclaimed land, and next along the two rivers and gradually extends offshore. At low tide the mud flat extends several kilometers off shore, and becomes a muddy field except near these two streams.

The sandpipers which have been resting on Yamato reclaimed land first gather on the outside mud flat of Hashimoto reclaimed land. While feeding

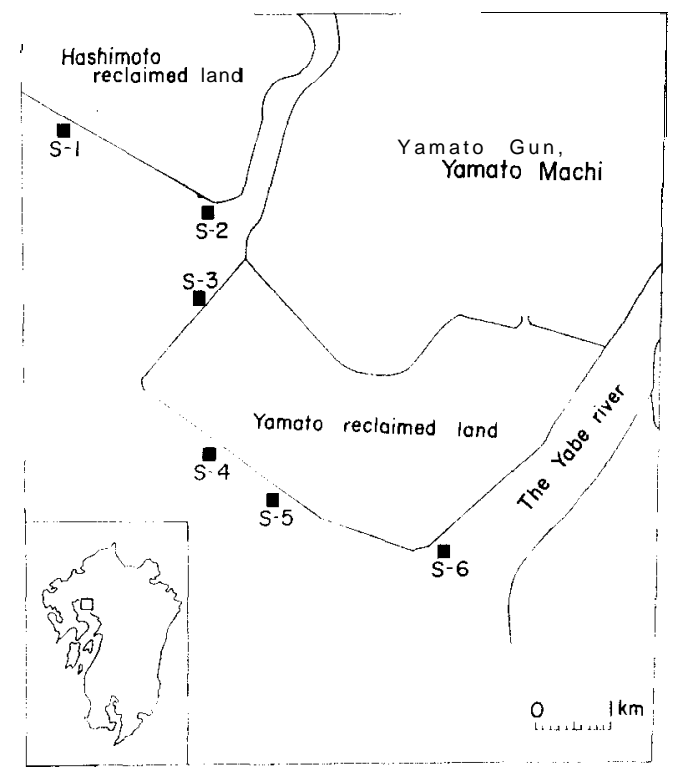

Fig. 1. Map showing survey stations of birds and invertebrates in the substrate. 
at the water's edge and following the tide, they move toward the broadening mud flat. The mud flats appear in front of Yamato reclaimed land after about an hour, and sandpipers gradually move out and finally disperse over nearly all the mud flats. As the tide moves in, the sandpipers follow the reverse course. At last they gather to the outside mud flat of Hashimoto reclaimed land again, and fly to return to Yamato reclaimed land.

\section{MATERIALS AND METHODS}

Birds for food analysis were captured by mist nets on Yamato reclaimed land on 5 September and 24 October in 1975, and we obtained 23 sandpipers in all. They consisted of five Asian Wandering Tattlers Tringabrevipes, eight Terek Sandpipers Xenus cinereus, six Dunlins Calidris alpina, two Wood Sandpipers T. glareola, one Common Sandpiper T. hypoleucos and one Red-necked Stint C.ruficollis. Stomach contents were found in 11 birds (two Asian Wandering Tattlers, three Terek Sandpipers, four Dunlins, one Wood Sandpiper and one Common Sandpiper). Those of the others were either empty or contained only several stones.

We set up six stations, of which four were around Yamato reclaimed land and two outside of Hashimoto reclaimed land, in order to examine the relation between not only the abundance but also the kinds of invertebrates, and the aggregation of birds (Fig. 1). On each station the survey line of $50 \mathrm{~m}$ in length was drawn from the shore toward the sea. We counted individual numbers of shorebirds which passed across the line for feeding during our continual observation from appearance to disappearance of the mud flat.

Six points were set up every $10 \mathrm{~m}$ from the shore along each survey line, and a substrate sample of the quadrate (measuring $25 \times 25 \mathrm{~cm}$ and $10 \mathrm{~cm}$ deep) was collected at each point. The mud was washed through a sieve (mesh size $1 \mathrm{~mm}$ ) and invertebrates retained on its bottom were fixed by $10 \%$ formalin. Wet weights were measured after identification to determine the value per centare. Exceptionally, on Station 3 which was situated on the estuary of the Shiotsuka river, only three points could be set up within $20 \mathrm{~m}$ from the shore. Thus, the other three points were set up toward the left at $10 \mathrm{~m}$ because the flat appeared as far as only $30 \mathrm{~m}$ from the shore on this station.

The observation of birds passing across the survey line was conducted in autumn (20 to 25 September in 1976) and spring (12 to 17 April in 1977). We collected invertebrates four times, in summer (9 to 29 July), in autumn (28 to 29 September) in 1976, in spring (4 to 6 May) and in winter (7 to 8 December) in 1977.

\section{RESULTS}

\section{Food habits}

The wet weights of stomach contents were respectively $0.23 \mathrm{~g}$ and $0.52 \mathrm{~g}$ (T. brevipes), $0.65 \mathrm{~g}, 0.67 \mathrm{~g}$ and $0.2 \mathrm{~g}$ (X. cinereus), $0.34 \mathrm{~g}, 0.6 \mathrm{~g}, 0.44 \mathrm{~g}$ and $0.5 \mathrm{~g}$ 
Table 1. Food items occurring in the gizzard contents of the sandpipers.

\begin{tabular}{|c|c|c|c|c|c|}
\hline & $\begin{array}{l}\text { Calidris } \\
\text { alpina } \\
\text { (4) }\end{array}$ & $\begin{array}{l}\text { Xenus } \\
\text { cinereus } \\
(3)\end{array}$ & $\begin{array}{l}\text { Tringa } \\
\text { brevipes } \\
\quad(2)\end{array}$ & $\begin{array}{c}\text { Tringa } \\
\text { glareola } \\
(1)\end{array}$ & $\begin{array}{l}\text { Ty inga } \\
\text { hypoleucos } \\
\text { (1) }\end{array}$ \\
\hline $\begin{array}{l}\text { Gastropoda } \\
\text { Fluviocingula nipponica } \\
\text { Ellobium chinense } \\
\text { Salinator takii } \\
\text { Others }\end{array}$ & $\begin{array}{r}54 \\
1 \\
2 \\
3\end{array}$ & $\begin{array}{l}2 \\
1\end{array}$ & & 1 & \\
\hline $\begin{array}{l}\text { Bivalvia } \\
\text { Arcidae } \\
\text { Veneridae } \\
\text { Tellinidae }\end{array}$ & $\begin{array}{l}+ \\
+ \\
+\end{array}$ & & & & \\
\hline $\begin{array}{l}\text { Polychaeta } \\
\text { Neanthes japonica (jaws) }\end{array}$ & 70 & 69 & & & \\
\hline $\begin{array}{l}\text { Crustacea } \\
\text { Leucosia sp. (claws) }\end{array}$ & & + & + & & \\
\hline $\begin{array}{l}\text { Insecta } \\
\text { Orthoptera (mandibles) } \\
\text { Hymenoptera }\end{array}$ & + & & & + & $\begin{array}{l}4 \\
3\end{array}$ \\
\hline $\begin{array}{l}\text { Sipunculoidea } \\
\text { Amphibia } \\
\quad \text { Rana limnocharis (skeletons) }\end{array}$ & & + & & $\begin{array}{l}+ \\
+\end{array}$ & + \\
\hline
\end{tabular}

Figures in parentheses show numbers of birds examined.

(C. alpina), 0. $05 \mathrm{~g}$ (T. glareola), 0. 36g (T. hypoleucos). The results of analysis were summarized in Table 1.

In C. alpina were found Neanthes japonica (Polychaeta), Fluviocingulanipponica, Salinator takii and Ellobium chinense (Gastropoda). The rest of stomach contents consisted of several pieces of bivalve molluscs and fragments of insects. N. japonica and F.nipponica were abundant.

In X. cinereus the invertebrates found were as follows: N. japonica, F. nipponica and S. takii which were the same species as in the stomachs of C. alpina, several fragments of meat of Sipunculoidea and a carapace of Brachyura. In $\mathbf{T}$. brevipes there were a part of the movable finger and other fragments of Leucosia sp. (Brachyura), but nothing except the crab. In T. glareola a number of skeletons of Rana limnocharis (Amphibia) were found in addition to Sipunculoidea, F. nipponica and several pieces of insects. In T. hypoleucos were found no invertebrates which lived in the substrate, but ants (Hymenoptera), locusts (Orthoptera) and many pieces of skeletons of R. limnocharis.

2. The relation between the invertebrates in the substrate and the aggregation of birds

The relation between the invertebrates and the aggregation of birds in autumn, 1976 was shown in Fig. 2. The invertebrates collected were identified as Bivalvia, Gastropoda, Polychaeta and Crustacea.

Looking at total weights of invertebrates, Station 4 showed the largest value, followed by Stations 5, 1, 3, 6, and the smallest on Station 2. The greatest number of birds were counted on Station 1, and followed by Station 4, 5, 6 and 2. The minimum number of birds was shown on Station 3. Compar- 


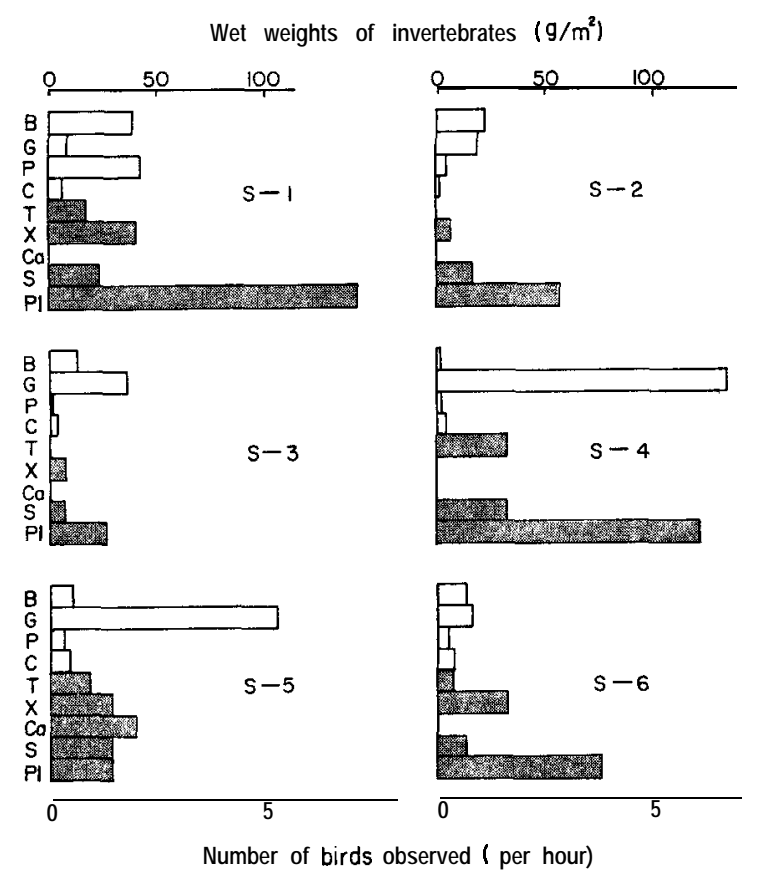

Fig. 2. Relation between invertebrate food organisms and aggregation of birds on each station in autumn, 1976. B, Bivalvia; G, Gastropoda; P, Polychaeta ; C, Crustacea ; T, Tringa brevipes ; X, Xenuscinereus ; Ca, Calidris alpina; S. Other sandpipers; Pl, Plovers.

ing the total wet weight of invertebrates with the total number of birds, it appeared that the station which had the most invertebrates was not always the station with the maximum number of birds. Also, minimum quantity of invertebrates did not necessarily correspond with minimum number of birds. We, therefore, decided to analyse a relation between each invertebrates and a bird species.

The greatest number of $T$. brevipes was on Station 4 , followed by $5,1,6$, and none of this species on either Station 2 or 3 . Because several fragments of crabs were found in stomach contents (Table 1), the distribution of $T$. brevipes was compared with that of Crustacea. The amount of Crustacea on stations where T.brevipes was observed was a bit more than on other stations, but Crustacea was also found a little even on Stations 2 and 3 where no $T$. brevipes was observed.

We further examined each wet weight composition of the crustaceans on each station after dividing them into three groups, i. e. 1) Grandidierella japonica, 2) Macrophthalmus japonicus and 3) other crustaceans (small shrimps, including Alpheus brevicristatus, Palaemon paucidens etc.) (Table 2). M. japonicus was known to show a very small proportion on Stations 2 and 3 where no $T$. brevipes was found. Therefore, it is found that the distribution of $T$. brevipes in this area has a closer relation with that of Brachyura rather than that of 
Table 2. Wet weight composition of Crustacea on each station in autumn, 1976.

\begin{tabular}{|c|c|c|c|c|c|c|}
\hline \multirow{2}{*}{ Species } & \multicolumn{6}{|c|}{ Weight composition on each station (\%) } \\
\hline & S-1 & $\mathrm{s}-2$ & $s-3$ & s- 4 & s- 5 & S-6 \\
\hline \multirow{2}{*}{$\begin{array}{l}\text { Grandidierella japonica } \\
\text { Macrophthalmus japonicus } \\
\text { Others }\end{array}$} & \multirow{2}{*}{$\begin{array}{c}0 \\
76.1 \\
23.9\end{array}$} & \multirow{2}{*}{$\begin{array}{r}1.0 \\
98.0\end{array}$} & 99.7 & 57.7 & 32.8 & \multirow{2}{*}{$\begin{array}{r}7.6 \\
45.4 \\
47.0\end{array}$} \\
\hline & & & $\begin{array}{l}\mathbf{0 . 3} \\
0\end{array}$ & $38: 5$ & 67.2 & \\
\hline
\end{tabular}

either Gammaridea or Macrura.

Concerning the distribution of $\mathrm{X}$. cinereus, we counted the largest number of them on Station 1, followed by Stations 6, 5, 3, 2, and none on Station 4 at all. As many N. japonica were found in their stomach contents (Table 1), the distribution of Polychaeta was compared with that of X. ci nereus. As a result, it was known that the amount of polychaetes was the greatest on Station 1 where the largest number of $X$. cinereus was found, and that polychaetes were relatively common on Stations 6 and 5, where many $X$. cinereus were counted. However, $X$. cinereus was found even on Station 3, where there were few polychaetes. On the other hand, on Station 4, which had no X. cinereus, polychaetes were found a bit more than on Station 3. From the above evidence, the distribution of $X$. cinereus seemed to be not always closely related with that of Polychaeta.

C. alpina was found only on Station 5. We attributed the reason to the fact that our examination was unfortunately carried out just on the early days of its migration, so that we failed to find any C. alpina on Stations 1 and 2, where a large number of them were usually observed. The other sandpipers were the Greenshank T. nebularia, the Whimbrel Numenius phaeopus, the Australian Curlew N. madagascariensis, the Great Knot and others, but the numbers of them were not so great because of our missing the peak of their migrations. Accordingly we could not discuss any relation between these kinds of birds and invertebrates in the present paper.

A large part of plovers consisted of the Kentish Plover Charadrius alexandrinus, and this species was found in the largest number on Station 1, followed by Stations 4, 6, 2 and 5 . The minimum number of this kind of plover was counted on Station 3. However, no invertebrate had a close relation with the distribution of the plovers.

The result of the examination carried out in spring, 1977 was shown in Fig. 3. In this examination, sandpipers were divided into four groups: 1) $C$. alpina, 2) C. tenuirostris, 3) the Bar-tailed Godwit Limosa lapponica and 4) other sandpipers. Invertebrates were richest on Station 6 , being followed by Stations 1, 5, 3 and 4, and poorest on Station 2. Comparing with the result in autumn, it was remarkable that Station 4 was reverse in the order of amounts of invertebrates against Station 6 , but the orders of other stations in these two seasons were not much changed. It was on Station 1 that the largest number of birds was counted, being followed by Stations 2, 4, 6 and 5 . No bird was observed on Station 3. Therefore, it was confirmed that the station 


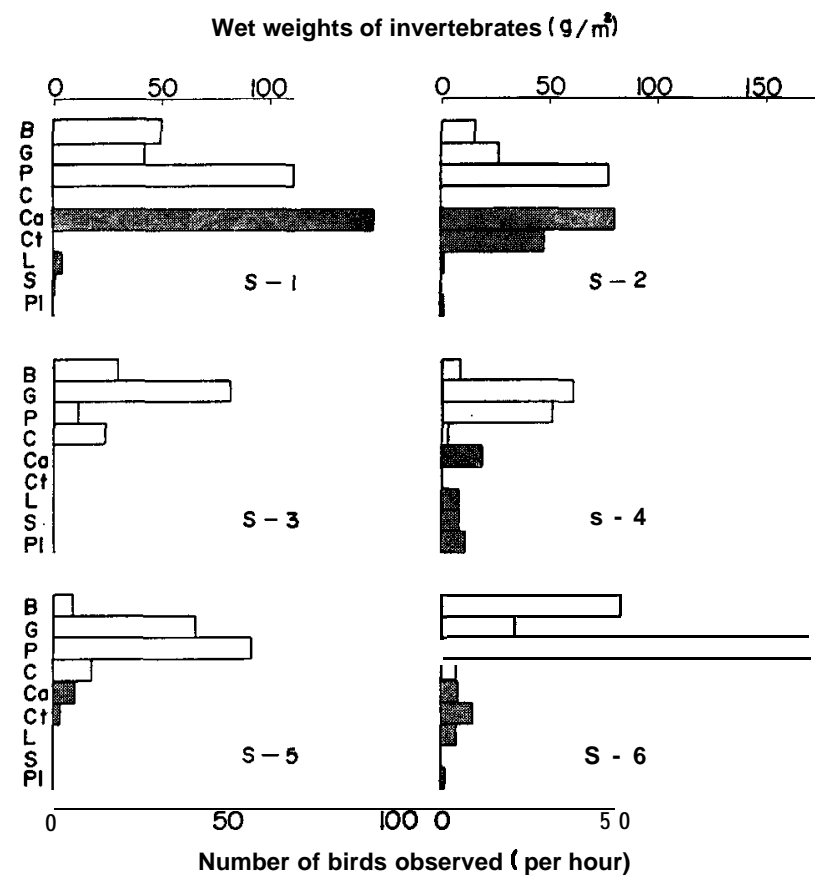

Fig. 3. Relation between invertebrate food organisms and aggregation of birds on each station in spring, 1977. B, Bivalvia; G. Gastropoda; P, Polychaeta; C, Crustacea; Ca, Calidris alpina; Ct, C. tenuirostris; L, Limosa lapponica; S, Other Sandpipers; P1, Plovers.

with the largest amounts of invertebrates was not necessarily the station where the largest number of birds was counted. On the contrary, we found no bird on Station 3 where the invertebrates were known to inhabit in nearly the same amounts as in autumn.

On Station 1, C. alpina was counted most abundantly, followed by Stations 2, 4, 5 and 6, but not on Station 3. C. tenuirostris was richest on Station 2, followed by Stations 6 and 5, but not on Stations 1, 3 and 4 . The largest number of L. Iapponica was observed on Station 4, being followed by Stations 6, 1 and 2. There was no bird on Stations 3 and 5. Other sandpipers observed were the Spotted Redshank T.erythropus,T.nebularia and C. ruficollis. Plovers included $\mathrm{C}$. alexandrinus and the Mongolian Plover $\mathrm{C}$. mongolus. At moment we can not discuss the relation between aggregation of these other kinds of sandpipers and the plovers and invertebrates, due to insufficiency of materials.

Many gastropods such as F. nipponica and a number of polychaetes N. japonica were found in the stomachs of C. alpina in autumn. We, therefore, examined the relation between the distribution of C. alpina and that of Gastropoda and Polychaeta in spring. Gastropoda was richest on Station 3, and followed by Stations 5, 4, 1 and 6. Poorest was Station 2. Consequently it was guessed that the distribution of C. alpina did not depend much on the 
Table 3. Wet weight composition of Gastropoda on each station in spring, 1977.

\begin{tabular}{|c|c|c|c|c|c|c|}
\hline \multirow{2}{*}{ Species } & \multicolumn{6}{|c|}{ Weight composition on each station $(\%)$} \\
\hline & s- 1 & $\mathrm{~s}-2$ & $\mathrm{~s}-3$ & $\mathrm{~s}-4$ & s- 5 & S-6 \\
\hline $\begin{array}{l}\text { Fluviocingula nipponica } \\
\text { Salinator takii }\end{array}$ & $\begin{array}{r}19.6 \\
4.1 \\
8.8\end{array}$ & $\begin{array}{r}71.1 \\
3.2\end{array}$ & 43.5 & $\begin{array}{r}52.5 \\
2.6\end{array}$ & $\begin{array}{r}66.1 \\
2.2\end{array}$ & 31.9 \\
\hline Littoraria scabra & $67: 5$ & 24. 1.07 & 32.16 .91 & 39.9 & 24.0 & $3928: 83$ \\
\hline
\end{tabular}

amount of Gastropoda.

Next, we divided gastropods on each station into four groups as follows: 1) F. nipponica, 2) S. takii, 3) Littoraria scabra and 4) others (Table 3). On Station 1 where the largest number of C. alpina was found, percentage of $F$. nipponica against all gastropods was smallest among the 6 stations, while on Station 2 where the largest number of $\mathrm{C}$. tenuirostris was counted, that of this gastropod was largest. On Station 3, where neither C. alpina nor C. tenuirostris was observed, L. scabra occupied a large proportion of Gastropoda. The largest quantity of polychaetes was found on Station 6, and followed by Stations 1, 5, 2 and 4. Their amount was minimal on Station 3. Polychaeta consisted of N. japonica, Cirriformia tentaculata, Capitella capitata and others (Table 4). From this table, it was known that N. japonica was the most abundant Polychaeta on Stations 2, 4, 5 and 6, and that on Station 1, which showed the largest number of C. alpina, the percentage of C. capitata was nearly same as of N. $j a$. ponica. On the other hand, on Station 3, where no sandpipers aggregated, C. tentaculata was abundant but $N$. japonica was absent.

Table 4. Wet weight composition of Polychaeta on each station in spring, 1977.

\begin{tabular}{|c|c|c|c|c|c|c|}
\hline \multirow{2}{*}{ Species } & \multicolumn{6}{|c|}{ Weight composition on each station (\%) } \\
\hline & $S-1$ & $s-2$ & $s-3$ & s- 4 & $s-5$ & S-6 \\
\hline Neanthes japonica & 52.6 & 88.0 & 82.4 & 92. 5 & 901 & 98.8 \\
\hline $\begin{array}{l}\text { Capitella capitata } \\
\text { Others }\end{array}$ & $\begin{array}{r}41.7 \\
0.7\end{array}$ & $3: 11$ & $\begin{array}{r}5.7 \\
11.9\end{array}$ & 5.2 & $0^{\prime}$ & 1.0 \\
\hline
\end{tabular}

Seasonal changes in the amounts of invertebrates on each station are shown in Fig. 4. First of all, it is known that polychaetes showed the largest quantity in spring, 1977, and their quantity on Station 3 was minimum at all seasons. It is also known that gastropods found in spring and autumn were abundant, but fewer in winter, and that there were many gastropods on Stations 4 and 5 , but few on Station 1 in any season. On the contrary, many bivalves were found on Stations 1 and 2, and few on Station 4. In crustaceans there was not such a generalized tendency found as in the above three classes. 


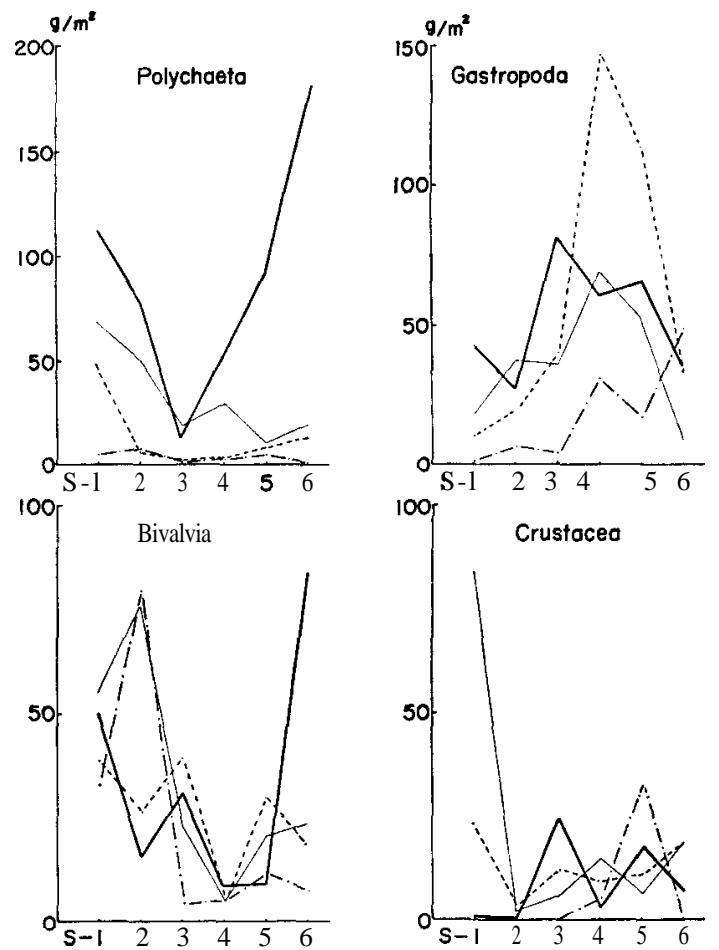

Fig. 4. Seasonal changes of wet weights of invertebrates on each station. - - summer; ...., autumn in 1976; - $\longrightarrow$, spring; •-•-, winter in 1977.

\section{DISCUSSION}

\section{Food habits}

Analysing 46 stomachs of C. alpina in California, Recher (1966) reported that $70 \%$ of them contained Nereis diversicolor (Polychaeta), and the rest Ostracoda, Amphipoda and so on. Bengtson and Svensson (1968) analysed 26 stomachs of C. alpina in southern Sweden and found many N. diversicolor in all of them. Ehlert (1964) also found N. diversicolor in $97 \%$ of 151 stomachs collected on Mellum near Helgoland. He further added that in both localities $\mathrm{C}$. alpina was remarkably stenophagous with $\mathrm{N}$. diversicolor which was by far the most important food.

On the other hand, Madon (1935) reported on the results of the analysis of 40 stomachs of C. alpina collected along the Atlantic coast of France that $\mathrm{N}$. diversicolor was found in $58 \%$ of them, molluscs in $40 \%$, crustaceans in 30 $\%$, insects in $30 \%$ and vegetable matter in $5 \%$. Comparing with those results of the analysis, the present stomach contents of C. alpina collected in the Sea of Ariake resembled that the result of Madon, and was somewhat different from those in southern Sweden and California. W. B. S. J. (1975) 
analysed only one stomach of C. alpina collected on Kasai, Tokyo Bay, and found four small bivalve molluscs, Musculus senhousia, and 11 jaws of N. japonica. Davidson (1971) reported that 24 stomachs of C. alpina collected in Morecambe Bay, Lancashire, England, showed that most of them contained small gastropods, Hydrobia ulvae, and polychaetes. These two results also resembled those of ours.

In North Alsaka which is situated in the higher latitude, C. alpina in the breeding season feeds on largely larvae and adults belonging to the families Tipulidae and Chironomidae of Diptera (Holmes, 1966). From examples above mentioned it is assumed that C. alpina changes its food habit in different localities where it stopps during its migration, and that its food content closely depends on the constitution and abundance of prey species in each locality.

Concerning T. brevipes, there is a report on one individual collected in the Edo river which runs into Tokyo Bay (W. B. S. J., 1975). According to it, only fragments of two crabs, Ilyoplax pusillus and $M$. japonicus were found, resembling our case where Leucosia sp. was found in the stomach of $T$. brevipes in the Sea of Ariake. Though the number of $T$. brevipes we examined is only two, it is assumed that in the Sea of Ariake the ratio occupied by crabs in food items of this sandpiper is fairly large.

Analysing method of stomach contents is very valuable as examining food habits. And it is the most important to decide the time when we collect birds in a day, because in the birds such as sandpipers which have spindle-shaped crops (Ziswiler and Farner, 1972), most food seemed to migrate directly into their proventriculi and gizzards, and be digested quickly. Among birds examined by us only one C. alpina had a full stomach. The analysed examples in foreign countries mentioned above were acquired from birds shot by gun while feeding. The collecting method by mist net is not suitable to obtain materials for the examination of stomach contents. It is important to devise the collection method most suitable for the examination of stomach contents of birds immediately after feeding.

\section{The relation between the invertebrates in the substrate and the aggrega- tion of birds}

Abe et al. (1965) and Migita and Oka (1977) have already reported on the results of investigations of invertebrates in the substrate on the north coast of the Sea of Ariake. Though substrate samples treated in those reports were many from the view point of whole of the Sea of Ariake, only a few were examined in the vicinity of Yamato reclaimed land. The Japanese Association for Preservation of Birds (1974) collected the substrate samples from the main 10 mud flats in Japan, and examined the relation between birds which aggregated and the invertebrates in each district. According to the paper 11 sample stations were settled for the purpose of investigations in the surrounding of Yamato reclaimed land, but the relation between shorebirds and invertebrates was not analysed in detail. On Kasai in Tokyo Bay the relation between invertebrates and the aggregation of birds was examined, and they re- 
ported that many shorebirds gathered in the station where many invertebrates were found (W. B. S. J., 1975). According to that report, the relation between each kind of invertebrates and both of C. alpina and C. alexandrinus which were observed in great numbers was also examined. It was concluded that the distribution of gammarids and nereids were closely related with that of these two species of birds. From our results, the station where the greatest amount of invertebrates was counted did not coincide with that showing the greatest number of birds in both spring and autumn. But many birds showed a tendency to aggregate on stations with relatively many invertebrates, and a few birds to aggregate on stations where a little invertebrates were found. However, there was also an example as Station 3 where few birds aggregated in spite of relatively many invertebrates in both spring and autumn. But the constitution of invertebrates was clearly different from those of other stations. So, it is not easy to relate simply the total amount of invertebrates with the aggregation of birds.

As a result of examination in autumn of 1976, T. brevipes has a close relation with the distribution of a limited prey species. Davidson (1971) also argued the food habits of the Knot C. canutus which has a similar body size and proportion of C. tenuirostris, being closely related each other. He described that most notable was the overwhelming occurrence of the bivalve mollusc Macoma balthica in the diet of the Knot in Morecambe Bay. H. ulvae was found in the greatest number of the stomach contents of C. canutus in Helgoland (Ehlert, 1964). Wolf (1969) reported that the distribution of C. canutus at the mouths of the Rhine, Meuse and Scheldt rivers, coincided exactly with the area in which the bivalve mollusc, Cardiumedule, occurred and H. ulvae was abundant, and that these small molluscs supplied the staple food of this kind of sandpiper. C. canutus, therefore, also seems to depend upon the considerably limited prey species as T. brevipes does. In Europe there are many C. canutus and no C. tenuirostris. On the contrary, in the Sea of Ariake we observed only a few C. canutus mixed sometimes in a large flock of C. tenuirostris (Hayashi and Kawaji, 1976; Kawaji et al., 1978). As these two species fed together on the same place, it is assumed that their food habits show a considerable resemblance.

Looking at the relation between the distribution of C. tenuirostris and that of bivalve molluscs in spring of 1977, there was no C. tenuirostris on Stations 1 and 3 in spite of relatively many bivalve molluscs. On Station 6 where bi-

Table 5. Wet weight composition of Bivalvia on each station in spring, 1977.

\begin{tabular}{|c|c|c|c|c|c|c|}
\hline \multirow{2}{*}{ Species } & \multicolumn{6}{|c|}{ Weight composition on each station ( $\not 6)$} \\
\hline & S - 1 & $s-2$ & $\mathrm{~s}-3$ & $s-4$ & $s-5$ & S- 6 \\
\hline $\begin{array}{l}\text { Moerella iridescens } \\
\text { Sinonovacula constricta } \\
\text { Glauconomya chinensis } \\
\text { Others }\end{array}$ & $\begin{array}{r}65.0 \\
32.3 \\
02.7\end{array}$ & $\begin{array}{r}7.7 \\
24.9 \\
0.1\end{array}$ & $\begin{array}{r}82.4 \\
6.3 \\
11.20 .1\end{array}$ & $\begin{array}{c}80.5 \\
0 \\
19.5\end{array}$ & $\begin{array}{c}73.9 \\
26.1 \\
00\end{array}$ & $\begin{array}{r}4.6 \\
86.9 \\
8: 05\end{array}$ \\
\hline
\end{tabular}


valves were most abundant, the proportion of Sinonovacula constricta was very large in all bivalves (Table 5). $S$. constricta in this season was yet young and about $1 \mathrm{~cm}$ in shell length. On the other hand, it was Station 2 on which $\mathrm{C}$. tenuirostris had been counted in the greatest number. It was the most remarkable feature on this station that Glanconomyachinensis occupied the highest ratio and was the most abundant in all stations, though this bivalve was also found on Stations 3 and 6 in spring of 1977.

As was mentioned above, in the Sea of Ariake it is assumed that C. tenuirostris tends to closely depend on small molluscs as C. canutus does in Europe. But at present we cannot discuss this relation extensively.

The aggregations of such bird species as X. cinereus investigated in autumn of 1976 and C. alpina in spring of 1977 did not depend on the distribution of any specific prey species. Wolf (1969) reported that the distribution of $\mathrm{C}$. alpina in the mouths of the Rhine, Meuse and Scheldt rivers agreed very well with that of $\mathrm{N}$. diversicolor. His report is also confirmed by the result of analysis of stomach contents examined by Ehlert (1964). However, C. alpina in Morecambe Bay makes use of several alternative prey species, depending on the densities and relative abundances of prey animals in different part of the bay (Davidson, 1971). As the ratio of each prey species occupied in all invertebrates is different in each area, $\mathrm{X}$. cinereus and $\mathrm{C}$. alpina feed chiefly on the most preferable prey in an area where it is abundant, but can change their food habits depending on the extent of their preference in areas where the most tasteful preys are scarce. On the contrary, it seems likely that birds do not aggregate on the area where target preys are scarce, however abundant other invertebrate prey may be.

\section{ACKNOWLEDGEMENTS}

We wish to express our thanks to Professor T. A. Uchida for his constant guidance. Thanks are also due to Professor E. W. Jameson, Jr., California University, for his revision of this manuscript. We are grateful to $\mathrm{Mr}$. $\mathrm{H}$. Minei, Zoological Laboratory, Kyushu University, for his much help and valuable advice in identification of Crustacea, Mr. K. Sato, a member of The Malacological Society of Japan, who identified small molluscs, and some of the graduate students of Zoological Laboratory, Kyushu University, who helped us in collecting invertebrates.

\section{REFERENCES}

Abe, N., S. Watanabe, M. Inoue and T. Fujita 1965 Benthic fauna in laver forms. R eports of Ariake Fisheries Experimental Station, Fukuoka Prefecture. 77-91 (in Japanese>

Bengtson, S. A. and B. Svensson 1968 Feeding habits of Calidris alpina L. and C. minuta Leisl. (Aves) in relation to the distribution of marine shore invertebrates. Oikos, 19: 152-157

Davidson, I'. E. 1971 Some foods taken by waders in Morecambe Bay, Lancashire. Bird Study, 18: 177-186 
Ehlert. W. 1964 Zur Ökologie und Biologie der Ernlhrung einiger Limikolen-Arten. J. Ornith., 105: 1-53

Feare, C. J. 1966 The winter feeding of the Purple Sandpiper. British Birds, 59: 165-179

Goss-Custard, J. D. 1969 The winter feeding ecology of the Redshank (Tringatotanus L.). Ibis, 111: 338-356

Goss-Custard, J. D. 1970 The responses of Redshank (Tringatotanus L.) to spatial variations in the density of their prey. J.Anim. Ecol., 39: 91-113

Goss-Custard, J. D. and R. E. Jones 1976 The diets of Redshank and Curlew. Bird Study, $23: 233-243$

Hayashi, H. and N. Kawaji 1976 Avifauna on the north coast of the Sea of Ariake. Biologia Fukuokana, (16) : 8-12 (in Japanese)

Holmes, R. T. 1966 Feeding ecology of the Red-backed Sandpiper (Calidris alpina) in arctic Alaska. Ecology, 47: 32-45

Ikeda, S. 1956 On the food habits of Japanese birds. Ornithological and Mammalogical Report, (15): 1-95 (in Japanese with English summary)

Japanese Association for Preservation of Birds 1974 A report on the examination for the conservation of shorebirds. J. A. P. B., 33-36 (in Japanese)

Kawaji. N., S. Shiraishi and H. Hayashi 1978 Birds on the north coast of the Sea of Ariake I. Seasonal changes in number of species and individuals on the representative birds. Misc. Rep. Yamushina Inst. Omith. 10: 82-93 (in Japanese with English summary)

Madon, R. 1935 Contribution àl'étude du regime des oiseaux aquatiques. Alauda, 1: 60-84

Migita. Y. and K. Oka 1977 The biota of the tidal flats I. Distribution of benthos at the tidal flat of Ariake Bay. Collection and Breeding, 39: 58-63 (in Japanese)

Recher, H. F. 1966 Some aspects of the ecology of migrant shorebirds. Ecology, 47: 393407

Reeder, W. G. 1951 Stomach analysis of a group of shorebirds. Condor, 53: 43-45

Wild Bird Society of Japan 1975 A report on the birds in Kasai Park. W. B. S. J., 53-83 (in Japanese)

Wolf, W. J. 1969 Distribution of non-breeding waders in an estuarine area in relation to the distribution of their food organisms. Ardea, 57: 1-28

Ziswiler, V. and D. S. Farner 1972 Digestion and the digestive system. In "Avian Biology," Vol. 2, ed. by D. S. Farner and J. R. King, Academic Press, Inc., New York, pp. $343-430$ 